\title{
Evaluation of non-formal education management in Maluku Province, Indonesia
}

\author{
Patrisius Rahabav ${ }^{1}$, Threesje Roza Souisa ${ }^{2}$ \\ ${ }^{1}$ Educational Administration, Faculty of Teacher Training and Education, Pattimura University, Indonesia \\ ${ }^{2}$ English Language Education, Faculty of Teacher Training and Education, Pattimura University, Indonesia
}

\section{Article Info \\ Article history: \\ Received Jan 14, 2021 \\ Revised Aug 13, 2021 \\ Accepted Sep 14, 2021}

\section{Keywords:}

CIPP model

Evaluation

Management

Non-formal education

\begin{abstract}
The study was aimed at evaluating the management of non-formal education institution in Maluku Province. Mixed methods were applied to conduct the study with the population included all 24 accredited non-formal education institutions in Maluku Province in 2017-2018. The non-formal institutions namely Central Maluku Regency 2 Learning Centre Community Activities (PKBM), Southeast Maluku Regency 2 Course and Training Institute (LKP), and 1 PKBM, Buru Regency 2 LKP, and 1 PKBM, Tanimbar Islands Regency 6 PKBM and Ambon City 3 LKP, 6 PKBM and 1 Learning Activity Center. The sample of this study was 24 non-formal education institutions (population sample) with census techniques, and two educators and two learning residents were also involved be interviewed. In collecting the data, several instruments were implemented such as non-test techniques in the form of assessment rubrics, observation, interviews, and documentation studies. In analyzing the data, the context, input, process and product (CIPP) was used as the bases theory and it was analyzed through quantitative and qualitative descriptive analysis ways. The results of this study reported that non-formal education institutions in Maluku Province did not optimally in applying the principles of good governance in the institution management and it was categorized in low level based on the CIPP model of evaluation.
\end{abstract}

This is an open access article under the CC BY-SA license.

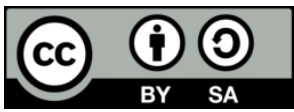

Corresponding Author:

Patrisius Rahabav

Educational Administration, Faculty of Teacher Training and Education

Pattimura University

Campus B FKIP, Jl. Dr. Tamaela, Ambon, Indonesia

Email: alifuruseram01@gmail.com

\section{INTRODUCTION}

Informal education is defined as a lifelong educational process where each individual gains attitudes, values, skills and knowledge gained from daily life experiences in the environment of family and neighbors, workplaces, playgrounds, markets, libraries and mass media [1]. Non-formal education (NFE) is defined as any organized educational activity outside the established formal system; carried out separately or integrating several broader activities; done deliberately to serve certain learning residents in order to achieve their learning goals [1].

Non-formal education is a reliable tool for the inculcation of social action [2]. It is a learning strategy that infuses ideas, knowledge outside of conventional school. Learning can occur in various locations; have relevance to the needs of disadvantaged groups; care about certain categories of individuals. Focus on clear goals, flexibility in organization and methods [3]. The presence of non-formal education institutions (NFE) is a social movement that needs to be appreciated, because it can help the government to educate some of the children that have no access to the formal education for some reasons [4]. The 
Government of the Republic of Indonesia continues to improve the management quality of non-formal education institutions. Therefore, since 2014, the non-formal education institution began to be accredited. Table 1 shows that the number of non-formal education institutions in Indonesia from 2014-2019 has continued to rise to 7,612 institutions, with details: Learning Centre Community Activities (PKBM) total 4,311 institutions and Courses and Training Institution (LKP) total 3,301 institutions. Regard to this statistic the data of non-formal education institutions in Maluku Province has been accredited by 24 institutions with the details: seven LKP institutions and PKBM/Learning activities workshop as many as 17 institutions.

Table 1. Amount of accredited non-formal education in Indonesia

\begin{tabular}{cccccc}
\hline \multicolumn{1}{c}{ Institutions } & & Year & \\
& 2014 & 2015 & 2016 & 2017 & 2018 \\
\hline Learning Centre Community Activities (PKBM) & 263 & 532 & 968 & 1,082 & 1,466 \\
Courses and Training Institution (LKP) & 732 & 809 & 591 & 456 & 713 \\
Total & 995 & 1,341 & 1,559 & 1,538 & 2,179 \\
\hline
\end{tabular}

The government's efforts led to quality improvement. However, it was realized that based on several groups' observation most of non-formal education institutions had not shown adequate quality. There are nine fundamental problems that trigger non-formal educational institutions not yet qualified: i) Economic motive factors; ii) Misconceptions about non-formal education factor; iii) Factors of inadequate qualifications and competency of the educators; iv) Factors of learning attitudes and habits of learning residents; v) Economic factors; vi) Factors of low awareness on Education; vii) Geographical factors; viii) The inability to utilize the environment as a source of learning and creative economic endeavors; and ix) The factor of limited access to information technology [5].

Moreover, when it was related to good management or good governance factor, it was also found that there were serious problems in almost all non-formal education institutions in Indonesia. Based on the observations of various parties, most of these institutions have not yet applied the principles of good management (good governance) [6]. In fact, Indonesia's territory is potentially rich in islands with beaches, lakes, mountain slopes, bio-diversity and cultural diversity. Most of the potential natural resources have not been well enjoyed by the people of this country. The problems were the inability to read market opportunities due to limited human resource. The non-formal education institution is still drowned in the safe zone and has not found the right formula to improve the quality and competitiveness of the institution effectively, efficiently, and productively [7].

The era of the industrial revolution 4.0 provided considerable opportunities for the non-formal education institutions to work on it. In that context, if all this time these institutions are still trapped in the old literacy, the accent is solely on the mastery of vocational and basic literacy (ability to read, write, and count/mathematics, then entering the revolution era 4.0). NFE institutions are required to apply new literacy. New literacy is focused on three main literacies, namely: digital literacy, technological literacy, and human literacy [8]. These three literacies are predicted to be skills that are very much needed in the future or in the industrial era 4.0. Digital literacy is directed at the aim of increasing the ability to read, analyze, and use information in the digital world (Big Data) [9], [10]. Technology literacy aims to provide an understanding of how machines work and technology applications, and human literacy is directed at improving communication skills and mastery of design science [11], [12].

The mastery of new literacy is expected to create competitive graduates by perfecting the old literacy movement which only focuses on improving reading, writing and mathematics skills [13], [14]. Workers in all fields in the industrial revolution era 4.0, both technical and managerial workers, are required to have digital skills. In addition, social skills are also a major prerequisite for workers in the industrial revolution 4.0 era [15]. In this context, the management of non-formal education institutions is very strategic. The management of these institutions in marine area is defined as the process of structuring the institutions by utilizing the potential of the islands simultaneously to support the achievement of the vision, mission and goals of these institutions effectively, efficiently and productively [16]. The synergy of the main elements of non-formal education institutions management in the industrial revolution era 4.0 can be described as program planning, program implementation, and program evaluation.

Program planning becomes the initial stage for non-formal education institutions to achieve excellence and competitiveness. Planning begins with a comprehensive assessment to mapping the potential and problems faced by these institutions. The plan involves internal and external stakeholders. The assessment data result is used as a reference to revitalize the vision, mission, goals, strategies, policies, programs, time, targets, key indicators, budget and program implementation procedures that will be regulated in two planning documents: strategic planning (RENSTRA) and operational planning (RKT/RENOP). 
Program implementation is the second stage for non-formal education institutions to implement the program that has been prepared. The implementation of the NFE program is prioritized on how to make the support capacity of the marine environment as well as the availability of means of communication and digital technology being effective. Facilities such as: Local TV, Frontier Radio, video conferencing, e-learning, video learning, e-mail, social media usage (WhatsApp, Facebook) can overcome the constraints of space and time limitations as a result of geographical constraints. Given the real condition of non-formal education institutions, the implementation of learning activities can be done online or in a network and offline or out of network. Therefore, learning can be done both classically and individually. Non-formal education institutions in the implementation of the program should move on from management with bad governance style by adopting practical management that prioritizes the principles of good and clean governance [17].

Program evaluation is the final stage to find out how far non-formal education institutions achieve performance targets according to the vision, mission, goals and targets set in the planning document. By doing the evaluation, it will be known what percentage of these institutions' absorption of the planned program, what are the problems and solutions for their improvement [18]. In addition, a performance evaluation and satisfaction index calculation were conducted either. Performance evaluation is done both to measure individual performance and the performance of the institution [19], [20]. In addition to performance evaluations, it is also necessary to conduct a survey of satisfaction of learning society towards the performance of educators [21], a survey of satisfaction of educators and educational staff towards the leadership of the institutions [22], surveys of public satisfaction levels toward the management of non-formal education institutions [23], tracer studies of the receiving ability of the graduates and the user satisfaction level toward the graduate performance [24].

English language skills and mastery of digital technology are prerequisites for non-formal education institutions to exist [25]. The success of the institutions in the future is very much dependent on the ability to synergize the potential of the sea-island, the ability of English and the use of digital technology [26]. Through digital technology and English language skills, the institutions have broad access to increase the number of learning society, reduce inefficiencies in various aspects, increase tourism promotion and tourist attractiveness, increases the volume of marketing products and services, open access to investment and new job opportunities that have implications on increasing revenue [27], [28]. The management of the institutions will thus have a multiplier effect both for learning society, surrounding communities and for the institutions itself. At this point, the institution will become an independent institution. In addition, they are no longer marginal institutions but will become mainstream institutions.

\section{RESEARCH METHOD}

This study applied mixed methods approach which mean that quantitative facilitating qualitative. This research variable was an independent variable, namely the evaluation of the non-formal institutions management. The institutional management evaluations in this study used the context, input, process, and product (CIPP) approach.

Context evaluation is intended to assess problems, assets and opportunities to help policymakers set goals and priorities and help other user groups know their goals, opportunities and results. Input evaluation is carried out to assess alternative approaches, action plans, staff plans, and funding for the continuity of the program in meeting the needs of the target group to achieve the stated goals. This evaluation has the benefit that policymakers can choose the design, funding allocation, allocation of implementing resources and schedule of activities that are most appropriate for the continuity of the program. The process evaluation is used to assess the implementation of the prepared plan to assist the implementers in carrying out activities and then will help other user groups know the program's performance and predict the results. Product evaluation is carried out by identifying and evaluating the results achieved both in the short- and long-term programs. Evaluation of results is identified from the impact, effectiveness, sustainability and adaptability [29]. Each of these dimensions is briefly interpreted as: i) Context: the situation or background that influences the planning of the development program; ii) Input: the quality of inputs that can support the achievement of the development program; iii) Process: the planned program implementation; and iv) Product: the results achieved in the implementation of the program.

The population of this study is all non-formal education institutions that have been accredited in Maluku Province in 2017-2018 are 24 institutions. The research sample was set to the population of the study, namely 24 non-formal education institutions (population samples) with census techniques whose details are as: Central Maluku Regency 2 PKBM, Southeast Maluku Regency, 2 LKP and 1 PKBM, Buru Regency 2 LKP, and 1 PKBM, Tanimbar Regency Island 6 PKBM and Ambon City 3 LKP, 6 PKBM and 1 Learning Activity Center. Based on the institute's sample, the main informants of this study were 24 institute leaders. In addition, two educators and two learning society are set to be interviewed based on purposive 
sampling. The first phase of interview was done for the leader of institution to discuss the scoring rubric assessment. The second interview was done for educators with aimed at crossing information gained from the leaders, and the third interview for the students/society who were involved in the program to find out the impact of following the program for their competence. Data collection techniques used in this study are nontest techniques in the form of assessment rubrics, observation, interviews and documentation studies. All the data gained from those instruments were analyzed intensively.

The data analysis technique used is quantitative and qualitative descriptive analysis techniques. Quantitative descriptive analysis techniques are used to analyze data obtained from the rubric of assessment. Table 2 illustrates the quantified management trend that quantified in the form of ranking. While the qualitative descriptive analysis technique, is used to analyze data obtained from observations, interviews and documentation studies. Besides, it is also used to explain further or give deeper meaning to quantitative analysis.

Table 2. Rubric assessment

\begin{tabular}{cc}
\hline Range score & Level \\
\hline $75 \%<x \leq 100=4$ & High \\
$50 \%<x \leq 75 \%=3$ & Fair/moderate \\
$25 \%<x \leq 50 \%=2$ & Poor/Low \\
$0 \%<x \leq 25 \%=1$ & Very poor/Very low \\
\hline
\end{tabular}

\section{RESULTS AND DISCUSSION}

\subsection{The context aspect}

Context dimension analysis, namely the level of achievement of accreditation results in eight national education standards. Since 2017-2018, there are 24 accredited non institutions in Maluku Province. There are two institutions (8\%) accredited A; 14 institutions (58\%) are accredited B; eight institutions (33\%) are accredited $\mathrm{C}$. The results of the achievement of eight national education standards are shown in Figure 1.

The percentage of non-formal education institutions' achievements on eight national education standards, three of the standards reached good category: standard 1, graduate competency standard (78.77\%); standard 2, content standard $(72.51 \%)$ and standard 5, infrastructure facilities $(72.11 \%)$ while the other five standards are on the moderate category (under $<70 \%$ ). From the five standards, the management standard has lower achievement percentage than others, namely (63.99\%); followed by financing standards is $67.10 \%$, education assessment standards are $68.18 \%$, process standards are $68.44 \%$, and $69.02 \%$ for educator and education staff standards. This data confirms that the achievements of the non-formal education institution in eight national education standards are generally in a sufficient category.

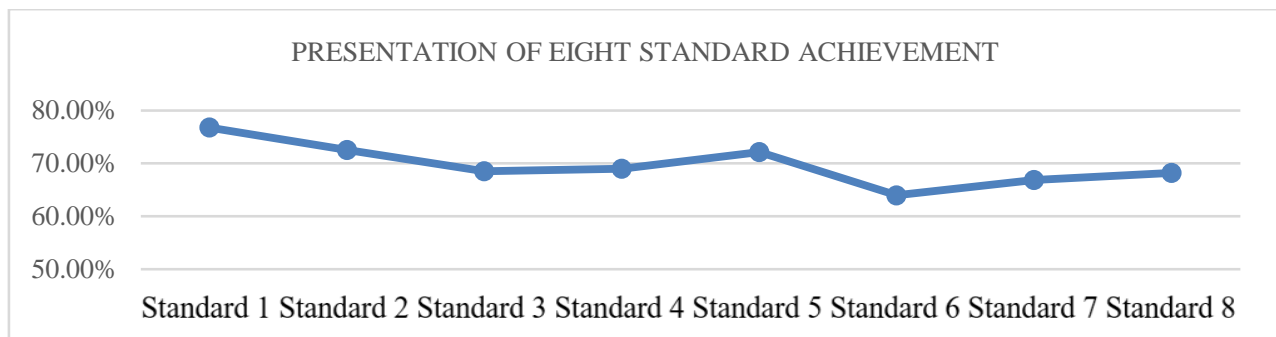

Figure 1. The results of the achievement of eight national education standards

The low achievement of these standards is surely their reasons follows. To dissect the problem, the results of our interview with H.A. (initial) one of the leaders of the non-formal education institute as:

"From my experience the non-formal education institution so far, has not been seen as an institution that equivalent to formal educational institutions. We try based on our capabilities but lack government support. In terms of quality, namely the fulfillment of 8 national education standards, we feel helped by the socialization and workshops given by assessors of BAN PAUD and non-formal education institution of Maluku Province." 
H.A. statement is following the documentation study that we conducted. Through document review, we found that most of the eight national education standards documents owned by the non-formal education institution were unfiltered documents (copied and paste). Most of these institutions did not have wellplanning documents. In this study we only found three strategic planning (RENSTRA) documents. While the annual planning (RKT) document is owned by most non-formal education institutions. Practical management such as guest books, agenda books, expedition books, inventory book, accounting/bookkeeping, minutes of meetings, reports, and arrangement of archives are not well ordered. We have encountered this condition at around $90 \%$ of non-formal education institutions. Based on the data, it can be said that the governance of non-formal education institutions, has not been placed under the principles of good governance. The result of input is shown in Table 3.

\subsection{Input}

Table 3 shows the total score of input dimensions obtained is 552. Most of the scores are in a small part category that is equal to 305 , followed by partially fulfilled 144 , no prove/not fulfilled are 47 and fulfilled is 56. The determination of categorization is based on the following criteria as it is shown in Table 4 . Total score of input dimension data collection $=552$. Thus, the percentage of input dimensions of 24 nonformal education institutions in Maluku $=552: 1,056=52 \%$. Based on the results of these calculations, in continuum way the categories can be seen in Figure 2.

Table 3. Dimension input

\begin{tabular}{|c|c|c|c|c|}
\hline Indicator & $\begin{array}{c}\text { No evidence/not fulfilled } \\
1\end{array}$ & $\begin{array}{c}\text { Score } \\
\text { Less fulfilled } \\
2\end{array}$ & $\begin{array}{l}\text { Half fulfilled } \\
\quad 3\end{array}$ & $\begin{array}{c}\text { Fulfilled } \\
4\end{array}$ \\
\hline 1. Strategic planning & 21 & 4 & 3 & 0 \\
\hline 2. Operational plans & 0 & 48 & 0 & 0 \\
\hline 3. Curriculum & 0 & 46 & 3 & 0 \\
\hline 4. Learning society input & 0 & 36 & 18 & 0 \\
\hline 5. Educator's input & 0 & 23 & 30 & 8 \\
\hline 6. HR manager input & 0 & 48 & 0 & 0 \\
\hline 7. Facilities and infrastructures input & 0 & 8 & 30 & 40 \\
\hline 8. Fund/Financing & 0 & 26 & 27 & 8 \\
\hline 9. Evaluation document & 0 & 24 & 36 & 0 \\
\hline 10. IT devices & 13 & 22 & 0 & 0 \\
\hline 11. Learning management & 12 & 20 & 6 & 0 \\
\hline Total score of input dimension $=552$ & 47 & 305 & 144 & 56 \\
\hline
\end{tabular}

Input dimension value: $(0 \%<\mathrm{x} \leq 25 \%=1 ; 25 \%<\mathrm{x} \leq 50 \%=2 ; 50 \%<\mathrm{x} \leq 75 \%=3 ; 75 \%<\mathrm{x} \leq 100=4)$

Table 4. Scoring rubric

\begin{tabular}{cc}
\hline Range score & Level \\
\hline $4 \times 11 \times 24=1056$ & High \\
$3 \times 11 \times 24=792$ & Fair/Adequate \\
$2 \times 11 \times 24=528$ & Low \\
$1 \times 11 \times 24=264$ & Very low \\
\hline
\end{tabular}

\begin{tabular}{|c|c|c|c|c|c|}
\hline 264 & 528 & & 792 & & 1056 \\
\hline $\begin{array}{l}\text { Very Low } \\
\text { High }\end{array}$ & & $\begin{array}{l}\text { Low } \\
552\end{array}$ & & Adequate & \\
\hline
\end{tabular}

Figure 2. The score of input

Based on this continuum line, the score 552 is between low to adequate intervals. Therefore, it was concluded that the non-formal education institution's input dimension score in Maluku was $52 \%$ (in the sufficient category). The results of interviews with informants about the input dimensions obtained as:

"To fulfill this input dimension through annual work plan which contained vision, mission, aims and annual programs, as well as 2013 curriculum plan document. The input improvement of learning society in each year around 20-30 people. We still lack of teaching staffs to fulfill 
our institution needs, and to manage the courses, two computer personnel work double as instructors and help us to organize the administration. Our financial support is obtained from the Government Operational Assistance and course fees from learning residents."

O.N. statement is in accordance with the documentation study that we conducted. Through the documentation study, we found that only three institutions had strategic planning (RENSTRA). RENSTRA is prepared by the head of the institution without involving external staff and stakeholders. Based on the results of the document review, the strategic plan prepared by three institutions did not meet the requirements of good RENSTRA preparation. For example, it does not start with environmental scanning. The strategic plan document owned by the institution, in the document review, we haven't seen a match between the vision, mission, goals and programs yet. RENSTRA is not equipped with performance indicators and unit costs. Non-formal education institutions generally have RKT documents. However, the RKT held is not done routinely; not through annual deliberations/mechanisms and not involving internal and external stakeholders. From the document review, we found that five institutions which has RKT for the past three years; other nine institutions, only has the one last year, while other 10 institutions haven't prepared RKT 2019 yet (RKT owned is RKT 2018). The institutional RKT is only 2-3 pages containing the program, implementation time, costs and is not completed with performance indicators. Specifically, three institutions that have RENSTRA, there we found that there was no consistency between the RENSTRA and the RKT.

The curriculum 2013 (K13) document is owned by all institutions. However, the K13 owned by the institute is the result of a copy-paste from the national curriculum and there are absolutely no modifications. The K13 document that we found was only document 1, whereas documents 2 and 3 owned by the institute were mostly not self-compiled documents but the results of copy-paste from a formal education institution.

The learning population is very varied. Data from the documentation study found that the population trend of learning residents is uncertain. Overall, the population trend of learning residents only increases by around $5-7 \%$ per year. The population is inadequate if it is associated with the standards that we set in this study which average increasing is $10-20 \%$ every year. There is no special selection for learning residents. The profile of them have not been well administered.

Most of the teaching staffs are bachelor graduates. However, most of the teaching staffs are workers hired from formal schools. Some non-formal education institutions have teaching staff, but the number is very minimal compared to the number of learning citizens. Training for supporting teacher competency has not been widely followed by them. One encouraging development is that the leaders of non-formal institutions have generally been involved in various professional organizations.

Most non-formal education institutions (70\%) do not have their own buildings (institution offices and houses become one), as much as $15 \%$ of institutions are renting and or borrowing, and another $15 \%$ have their own buildings. Non-formal education institutions generally have a leader office, teacher's room, practice room equipped with public bathing, washing, and toilet facilities. However, some institutions still borrow from formal school classrooms for learning activities. The learning support facilities that appropriate with curriculum is still very minimum. Non-formal education institution does not have inventory fund reserves for Institution development; doesn't have good records yet. Most institutions do not use general and supporting cash books, bank handbooks, tax assistant books, payment books and salary/honorarium books.

Non-formal education institutions mostly have not evaluated all institute activities yet. This is the evidence of the absence of annual evaluation report documents, performance evaluation and public satisfaction index. In addition to minutes of the meeting, we did not find the results of the supervision. Some institutions do not have internet networks yet, with sufficient capacity. The problem is due to isolation, electricity network that often goes out especially in outermost, underdeveloped, leading (3T) area. Besides, the financial capacity of the institute is not very helpful. Most institutions depend on government operational assistance funds.

Regarding to the process, there are five indicators: i) Application of Management information system (MIS); ii) Realization of RENSTRA and RENOP; iii) Implementation of learning management consistently; iv) Administration discipline; and v) Evaluation and monitoring. The result of the process is presented in Table 5.

\subsection{Process}

Table 5 shows a total score of process dimensions is obtained for 218. Most of the scores are in the category of a small part that is equal to 132, following no evidence/not as large as 53, partially met by 33 and a total of 20. The determination of categorization is based on Table 6 scoring rubric. Score of process dimension data collection=218. Thus, the percentage of process 24 dimensions of NFE institutions in Maluku=218: $480=45 \%$. Based on the results of these calculations, on a continuum the following categories as shown in Figure 3. 
Based on the continuum, a score of 218 , is between very low to low intervals. Thus, it was concluded that the NFE institutional process dimension score in Maluku was 45\%, (in the low category). The application of Management Information Systems (MIS) becomes a very important parameter in the governance of NFE institutions because a good MIS becomes a prerequisite for data and information availability for the leadership of the institution in making decisions. In addition, a good MIS, makes it easier for all parties to access various data and information available at the institution. This will enhance the image and public confidence in the NFE institution. A good MIS must meet the criteria for use: information boards, letters, suggestion boxes, information delivered quickly, easily accessed, using the web, WhatsApp groups, Facebook emails. In this study we found that most NFE institutions in Maluku have not managed MIS well. Most institutions already have social media such as: WhatsApp, Facebook, but it has not been used as an effective communication medium between the institution and learning residents, between the institution and external stakeholders. Social media is still used limited to delivering announcements or important information such as learning schedules, exams or other academic activities. Most institutions do not have a website yet. The use of email is still very limited.

Table 5. Process

\begin{tabular}{|c|c|c|c|c|}
\hline Indicator & $\begin{array}{c}\text { No evidence/not fulfilled } \\
1\end{array}$ & $\begin{array}{c}\text { Score } \\
\text { Less fulfilled } \\
2 \\
\end{array}$ & $\begin{array}{l}\text { Half Fulfilled } \\
3\end{array}$ & $\begin{array}{c}\text { Fulfilled } \\
4\end{array}$ \\
\hline 1. Application of MIS & 11 & 22 & 6 & 0 \\
\hline 2. Realization of RENSTRA and RENOP & 10 & 20 & 6 & 8 \\
\hline 3. Implementation of learning management consistently & 12 & 20 & 6 & 0 \\
\hline 4. Administration discipline & 10 & 28 & 9 & 8 \\
\hline 5. Evaluation and monitoring & 10 & 22 & 6 & 4 \\
\hline Dimension process total score $=218$ & 53 & 112 & 33 & 20 \\
\hline
\end{tabular}

Table 6. Scoring rubric

\begin{tabular}{lc}
\hline Range Score & Level \\
\hline $4 \times 5 \times 24=480$ & High \\
$3 \times 5 \times 24=360$ & Fair/moderate \\
$2 \times 5 \times 24=240$ & Poor/low \\
$1 \times 5 \times 24=120$ & Very poor/Very low \\
\hline
\end{tabular}

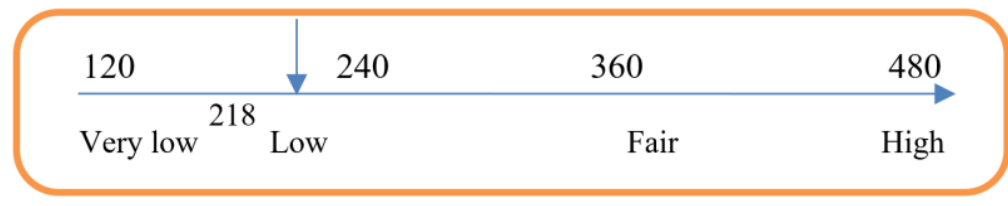

Figure 3. The score of process

As many as three NFE institutions already have RENSTRA documents and all institutions have RKTs. Through this study, we found that the planning documents (RENSTRA and RKT) did not meet the established standards. The ideal planning document must contain the vision, mission, objectives, indicators, programs and budget; it is not obeyed. Based on document review, we find that the RENSTRA and RKT documents have never been revised periodically. Informant A.R. (an educator), put forward as:

"Our institution has a strategic plan document and RKT document which are compiled by the head of the Institution which contains the vision, mission, goals and work program. Both documents have not implemented yet because of lack of funding from the institutions."

All NFE institution management ultimately leads to implementation in the classroom with learning residents. Therefore, good learning management is needed. The implementation of learning management in NFE institutions at least meets the criteria: lesson plan corresponding with the syllabus, main competence corresponding, basic competence, basic competence with indicators, indicators with the material, material with strategy, learning models, compatibility of the material with Educational Game Tools (APE), material with evaluation (HOTS questions), active students, balance between theory and practice, and flexible learning schedule. In this study, we found that the management of teacher learning at the NFE institution has 
not been well managed. J.M. one of the educators admits that the management of learning at the NFE institution had not been well-paid attention. Furthermore, J.M. explains:

"Our institution does not have complete curriculum documents yet. K13 document (document 1) that we have is referred to documents owned by formal schools. We also have not described in the syllabus which allows including local content. So, in teaching, I use a syllabus from my original school; As well as lesson plan, I use mine in high school. In teaching, I have used a scientific approach with the intention that learning residents to be active; study well. However, it is not easy. I have tried to motivate residents to learn by asking questions, discussions etc. however, learning residents are difficult to be active."

J.M. report is confirmed by the statement of the leader of the Institute. In our interview with W.J. it is admitted that they do not have curriculum documents, syllabus and lesson plans that are prepared by themselves because of time constraints. In fact, W.J. one of the teachers confessed that in teaching she sometimes did not use the lesson plan, as it is shown:

"We need more time in designing our teaching plans, and I realized that sometimes in my teaching practice I didn't prepare teaching plans because I used to teach the similar materials for several years. I had notes about my outline and it was useful for me to teach the students."

The explanation of the informant is in accordance with the document review. When we examined the curriculum, syllabus and lesson plan documents there, we found that the documents are the result of copy-paste. We are also trying to study the lesson plan documents of several teachers which they prepared themselves. Teacher's lesson plan documents after review, we found that between documents, there was a discrepancy both with the syllabus, indicators with material, material with strategy, learning models, compatibility of material with APE, material with evaluation (HOTS question). When we try to observe in several classes, we found that teachers teach without using lesson plans; even some teachers who use lesson plans, still having an inconsistency of their performance with the lesson plans that have been prepared. The teachers have not been able to use the K13 learning model, such as problem-based learning, project-based learning and inquiry-discovery learning in learning.

There is a strong tendency for some institutions to be very rigid with lesson schedules. Learning generally takes place in class. This was admitted by several informants that concerning the limited time given and they should finish the curriculum target, and then most of the learning took place in a formal classroom setting. The informant admitted that teachers did not use APE because it was not available at the institute; whereas the environment is quite supportive and can be used as a center for learning resources. IT-based learning such as distance learning, e-learning and online in our observations, has not been used. So, the accent of learning tends to be more centered on the teacher. This condition is found especially in institutions that hold equality education and English language courses. In contrast, in some institutions that conduct computer and beauty courses, the orientation of learning activities is more in practice.

In general, teachers have not been able to assemble questions that require higher-order thinking skills (HOTS). Curriculum organization and subjects at non-formal education institution, carried out separately; without seeing its coherence with other subjects. Academic and vocational aspects get more pressure while character education and life skills get less attention. This aspect has become a prerequisite for non-formal education graduates to have a high degree of excellence and competitiveness in the market.

The management of an institution is very simply reflected in clerical work. The criteria that we used in this study were orderly administrative with parameters: filled in a guest book, inventory book, goods lending book, main learning residents' book, minutes, supervision book, agenda book, expedition book, general cash book (GCB) and cash assistant book (CAB), monthly report book, inventory book, honorarium payment book, receipts, tax invoices, proof of electricity payment, water, telephone and documented annual reports. In this study, we found that the majority of non-formal education institutions did not organize their administration properly. Many books as mentioned are not found. Some institutions have a guest book, an inventory book, a note book, a supervision book, an agenda book, an expedition book, but they are left blank. Even if filled, it is not carried out in an orderly manner.

Evaluation and monitoring of programs and activities in non-formal education institutions meet the standards: monthly, semester annual evaluations, institutional and individual performance measurements, measurements of the community satisfaction index for management, the community satisfaction index for graduate competencies, supervision, and study tracers. To determine the extent of the successful implementation of the program at the non-formal education, an evaluation was conducted. A.A. one of the heads of the non-formal education institute explained that they had been evaluating and monitoring. 
"Evaluation and monitoring are done for instance through supervision that I do every time. Supervision activities are intended to monitor teacher performance so that there are things that are lacking, will be given suggestions for improvement. Besides supervision, I also conduct meetings with staff, although it's not routinely. Through this meeting, we discussed various issues both academic and non-academic. For example, meetings leading up to the implementation of the national exam, evaluation meeting for graduation of learning residents, meetings towards preparations for acceptance of learning residents etc."

When he was asked about more comprehensive monitoring and evaluation, for example, in terms of measuring the performance of institutions and individuals, measuring the index of community satisfaction with management, the index of community satisfaction with graduate competencies, supervision and research studies, A.A. claimed that they had never done it. A.A. report is following the statement of M.M. as:

"In this PKBM, meetings are rare; if there is, it is usually done before the national exam. There is another meeting indeed, which is the exhibition preparation meeting on August 17, 2017. Because we are obliged to participate, so we need a meeting to discuss the necessary preparations. Regarding to evaluation and monitoring in other forms such as performance evaluation and measurement of satisfaction index, as far as I know while serving as a teacher at PKBM, there is no such thing. Supervision activities both from the Foundation and the head of the Institute are rarely conducted."

Based on the analysis, it can be stated that the non-formal education institution, has not implemented the principles of good governance in improving the performance of the institute well. In terms of product, it consists of eight indicators such as: i) Academic achievement; ii) Non-academic presentation; iii) Output utilization presentation; iv) Appropriate technology mastery; v) Self-funding; vi) English skill literate; vii) IT mastery; and viii) Learning residents' population. Table 7 presents the result of the product.

\subsection{Product}

Table 7 informs the total score of input dimension is 349. Most of the scores are in the partially fulfilled category which is 117 , following that there is no evidence/not fulfill, in the amount of 112; a fraction fulfilled 104 and entirely fulfilled with total of 16. The determination of categorization is based on Table 8 of scoring rubric. Total score of product dimension data collection $=349$. Thus, the percentage of achievement of input dimensions of 24 non-formal education institutions in Maluku is 52\%. Based on the results of these calculations, on a continuum is shown in Figure 4.

Table 7. Product

\begin{tabular}{lcccc}
\hline \multicolumn{1}{c}{ Indicator } & \multicolumn{2}{c}{ Table . Product } & & \\
& No evidence/Not fulfilled & Sess fulfilled & Half fulfilled & Fulfilled \\
& 1 & 2 & 3 & 4 \\
\hline 1. Academic achievement & 0 & 0 & 60 & 16 \\
2. Non-academic presentation & 12 & 22 & 3 & 0 \\
3. Output utilization presentation & 14 & 22 & 12 & 0 \\
4. Appropriate technology mastery & 16 & 8 & 12 & 0 \\
5. Self-funding & 17 & 6 & 12 & 0 \\
6. English skill literate & 18 & 20 & 6 & 0 \\
7. IT mastery & 20 & 18 & 12 & 0 \\
8. Learning residents' population & 15 & 104 & 117 & 0 \\
Dimensional input total score $=349$ & 112 & 8 & 16 \\
\hline Dimensional product value: $(0 \%<\mathrm{x} \leq 25 \%=1 ; 25 \%<\mathrm{x} \leq 50 \%=2 ; 50 \%<\mathrm{x} \leq 75 \%=3 ; 75 \%<\mathrm{x} \leq 100=4)$ &
\end{tabular}

Table 8. Scoring rubric

\begin{tabular}{cc}
\hline Range score & Level \\
\hline $4 \times 7 \times 24=672$ & High \\
$3 \times 7 \times 24=504$ & Fair/moderate \\
$2 \times 7 \times 24=336$ & Poor/low \\
$1 \times 7 \times 24=168$ & Very low \\
\hline
\end{tabular}




\begin{tabular}{|lllll|}
\hline 168 & 336 & $\downarrow$ & 504 & 672 \\
\hline Very low & Low & 349 & Fair & High \\
\hline
\end{tabular}

Figure 4. The score of product

Based on the continuum line, the score 349 is between low to sufficient intervals (closer to enough). Thus, it was concluded that the non-formal education institution product dimension score in Maluku was $52 \%$, (in the sufficient category). Through documentation studies, we found encouraging developments that the academic achievements of learning residents were categorized as good. This is proofed by the percentage of UN graduations ranging from $75-100 \%$ each year; the average their learning achievement ranges from 70 80. The academic achievement of them is not directly proportional to non-academic achievement. In this study we found that learning residents were less able to show achievements in the arts and sports. Only a few of them that won sports and art competitions; even it is also the local level. National event held by the Ministry, Dirjen PAUD, and DIKMAS, namely PAUD \& Non-Formal Education Appreciation Week. The annual event was admitted by several institute leaders that representatives of the learning residents always participated but were only able to win the gold medal for the choir (group). While for the individual category, they have not been able to win any medals yet as it is shown:

"W.O. one of the teachers explained the reason why the learning resident had not been able to compete in national events because there was no training. W.O. admitted that at non-formal education institutions activities were more focused on regular learning whereas extracurricular activities that develop the interests and talents of learning residents have never been carried out. Learning residents are just prepared at least 1-2 weeks before they go to national events such as PAUD and Non-Formal Education appreciation. Thus, it is likely that they cannot achieve top performance."

One of the parameters used to measure products is the percentage of output utilization. Based on the results of interviews with informants, it was found that the output of non-formal education institutions on average ranged from $30-40 \%$ to be accepted in higher schools (junior high, high school and university); the average that goes straight to work is around 10-20\%; as many as $15-20 \%$ of graduates can create jobs (entrepreneurship). Most non-formal education institutions in Maluku based on this study have not been able to produce appropriate technology in sufficient quantity and quality. From our observations we have observed that several products have been made, for example, eucalyptus oil refining, the shellfish industry, shredded, convection and weaving. The product is good but the problem is that the same product is also produced by the local community. P.J. one of teacher explained as:

"The learning residents, together with us has produced woven fabrics, but they cannot compete in the market because the local generally produces and sells the same products."

M.N. one of the leaders of the Institute explained:

"We have also been trying to produce the shellfish industry. The work of the residents is very good. However, the learning residents, when they graduate do not continue it as business activities that have economic value."

Independent funding is one of the core strengths that determine the longevity of a non-formal education institution. The acquisition of independent funds in this study is measured by parameters: having a school canteen, a school cooperative, a school garden, a livestock business, appropriate technology that marketable, parent assistance and partnerships with the Business and Industrial World (DU/DI). Results of interview with H.A. one of the leaders of the non-formal education institute as:

"Independent funding is one of our priorities. So far, we have continued to strive towards this direction because our dependence so far has only been on honestly inadequate Government Operational Assistance (BOP) funds. We just tried with the cage business. The results are pretty good. On average each month, we make a profit of 2-3 million rupiah. Other businesses 
such as: having a school canteen, a school cooperative, a school garden, a livestock business, appropriate technology that marketable, parental assistance and partnerships with the Business World and the Industrial World (DU/DI) have not been promoted."

H.A. explanation is following the statements of several non-formal education institution leaders and the results of our documentation study in the institutional books. In our review of the bookkeeping of the Institute, we did not find any residual funds from the results of operations or reserve funds for the benefit of long-term institution development. Cash is always zero (no reserves or residual) as well as in a bank account. So, practically the non-formal education institution only depends on funding expectations on Government Operational Assistance (BOP) funds.

The mastery of IT and English is a prerequisite for the output of non-formal education institutions to be able to compete in the workforce. According to A.A. one of LKP's leaders said that the graduates mastered English well. A.A. reports is correspond to a simple test that we do. Three graduates, who were successfully contacted by telephone, were able to communicate in English well. Further information that we collected from several institutional leaders regarding the use of graduates' English language skills was admitted by two leaders of the English language LKP that their graduates had become guidance.

In addition to mastering English, information and technology (IT) skills are generally dominated by learning residents who take IT courses. This is proofed by the observations and tests conducted on two LKPs that held computer courses. From the results of our observations and tests, the IT skill of the average learning residents is quite good. They generally have basic skills: MS Word, Excel, PowerPoint, and internet access.

English and IT skills are not shared by all other non-formal education institution graduates. W.N. and W.O. during the interview both confessed that English and IT skills were not well-owned by all graduates. Furthermore, W.N. explained as:

"English in our PKBM is only 1 semester while in IT, we rarely practice because we only have two units of computers. With only one semester and little amount of face-to-face meetings, I admit it is difficult for society to master English well. Likewise, the number of computers is limited; it certainly has an impact on their mastery of IT."

Our interview with several non-formal education institution leaders about IT mastery, it was admitted that in aggregate, learning residents who mastered IT ranged from $20-30 \%$. This percentage is still far from the ideal presentation (70-80\%).

The population of learning residents at the non-formal education institution fluctuates every year. The trend of the learning residents' population every year is uncertain and even involute (not rising, not decreasing/stagnant). According to several non-formal education institution leaders, the average population of learning residents ranged from $2-7 \%$. This number is lower compared to the standard we set in this study, which is a minimum of $10 \%$ each year. Based on the explanation of several non-formal education institution leaders, concerning the minimal learning population, the selection of prospective learning residents was eliminated. No matter how many of them who registered, they all are accepted.

The results of this survey show that the non-formal education institution in Maluku Province has not applied the principles of good governance in the management of non-formal education institutions. The root of the problem: i) Ignorance of the non-formal education institution management of good governance principles as a result of lack of training; ii) There is no good will of management to manage the institution professionally; iii) Lack of guidance and assistance of related institutions (District/City education and sports service) and BP PAUD and Provincial Dikmas; iv) Weak supervision of funding agencies including audit institutions (Inspectorate and BPKP/BPK). Evaluation of the context dimension, obtained data that the results of the accreditation achievement, only three standards, namely graduate competency standards, content standards and infrastructure standards that get good categories. While the other five standards, namely management standards, financing standards, education assessment standards, process standards, and the standards of educators and education personnel are in the sufficient category.

Evaluating the input dimension, we found that from 11 parameters surveyed, the performance of non-formal education institution was still in the low category. Planning documents, for example, it was found that the institute does not have regular RENSTRA yet and RKT planning documents, as well as curriculum documents that the institute does not have. Institutions tend to copy-paste the curriculum owned by formal educational institutions. Curriculum organization and subjects at non-formal education institution, carried out separately; without seeing its coherence with other subjects. Academic and vocational aspects get more pressure while character education and life skills get less attention. These aspects have become a prerequisite for non-formal education graduates having a high degree of excellence and competitiveness in the market. Life skills refer to soft skills divided into three categories: i) Social or interpersonal skills which include 
communication, negotiation and rejection abilities, assertiveness, cooperation and empathy; ii) Cognitive skills that involve problem-solving, sequence understanding, decision making, critical thinking and selfevaluation; and iii) Emotional coping skills that include self-positive feelings and self-control used in managing stress, feelings and mood [30].

Non-formal education is different from formal education. Non-formal education is flexible in terms of methodology, but learning is not accidental, but deliberate and organized. Students' needs and interests are being realized in less time. Besides, the contacts between learning residents and instructors are less significant and most learning takes place outside the classroom and institution. Non-formal education focuses or accentuates on skills and develops attitudes such as tolerance for one's future success. Studies show that learning resident's needs are better fulfilled through non-formal education that enables them to get to know themselves and the better world. In general, non-formal education is open and flexible for the needs and interests of them and is responsive towards changes in individual and community needs [31]. Non-formal education should be given in the interests of learning residents and that organization and curriculum planning should be carried out by involving students themselves. So, it must be "bottom up". In other words, it must empower them to understand and if necessary change the social structure around them [32].

Learning management such as syllabus and lesson plans are copied and paste from formal schools and even some teachers teach without using lesson plan. Another weakness we found was that the number of learning residents every year fluctuated. Even though most of the teaching staffs are bachelor, most of them are teachers in formal schools. Some part of the building that used is under loan status/ownership rights, the other part is owned, but also used as a residence.

Non-formal education institution does not have fund reserves for institutional development and does not have good records. Non-formal education institutions mostly have not evaluated all institute activities yet. This is proofed from the absence of annual evaluation report documents, performance evaluation and public satisfaction index. IT is still a particular obstacle because most Institutions do not have an internet network yet, with adequate capacity. The problem is due to isolation, the electricity network that is often extinguished, especially in the region of $3 \mathrm{~T}$. Besides, the financial capacity of the institute is not very supportive.

An evaluation of the process dimension, it found that from the five parameters surveyed, the performance of the non-formal education institution in Maluku was in the unfavorable category. MIS has not been implemented well. Even if MIS is a prerequisite for the availability data and information for the leadership of the institute in decision making. A good MIS will also make it easier for all parties to access various data and information available at the Institution so that it will enhance the public image and trust of the non-formal education institution. In this study we did not find consistency between planning documents (RENSTRA and RKT). Thus, the planning document becomes a perish document or can be said to be simply held to meet formal demands because it is one of the accreditations demands, but it is not implemented. In learning management it's also found that there is no compatibility between written documents (syllabus with lesson plans) and between lesson plans with material, learning strategies, evaluations and between lesson plans and teacher performance; even between theory and practice. Teacher accreditation is still on compliance and not on performance. Practical management activities, there has not been an orderly administration. Monitoring and evaluation either through supervision, monthly, annual evaluations, performance measurements and public satisfaction and retail studies have not been conducted.

One problem that is difficult to solve is that, it is difficult for teachers to activate learning residents to ask and discuss. This condition can actually be overcome if the non-formal education has adequate Information and communication technology (ICT) infrastructure. ICTs has infiltrated all areas of life. In this case the understanding of digital competence has been expanded from basic computer skills to sophisticated skills of using and producing digital media, information processing, and participating in social networks to create and share knowledge. Besides, the application of ICTs at all levels of education can make the learning process more personal, adaptive and interactive [33].

An evaluation of the product dimension found that of the eight parameters surveyed, the performance of the non-formal education institution in Maluku was in the moderate category. The average learning achievement of learning residents ranges from 70-80. The academic achievement of them is not directly proportional to non-academic achievement. In this study we found that they were less able to show achievements in the arts and sports. Non-formal education institution outputs on average 30-40\% are accepted in higher schools (junior high school, senior high school, and college); the average graduate directly works around $10-20 \%$ and as many as $15-20 \%$ of graduates can create jobs (entrepreneurship).

Most non-formal education institutions in Maluku based on this study have not been able to produce appropriate technology in sufficient quantity and quality. From our observations we have found that several products have been produced. The product is good but the problem is that the same product is also produced by the local community, so that the non-formal education institute's products are less competitive in the market. Non-formal education institutions do not have reserves of the remaining funds resulting from 
operations or reserve funds for the benefit of long-term institution development. So, practically the nonformal education institution only depends on funding expectations on BOP funds. Without BOP, the institution is closed. Another problem is the level of mastery of English and IT of the learning residents/graduates as a whole is not good. The implication is the trend of their population every year experiencing involute symptoms (not rising, not falling/stagnating).

\section{CONCLUSION}

The study found that non-formal education institutions in Maluku Province have not fully applied the principles of good governance in the management of non-formal education institutions. Evaluation of the context dimension, the data obtained is the results of the accreditation achievement of eight national education standards are only three standards, namely the graduate competency standards, content standards and infrastructure standards that get good categories. While five other standards, namely management standards, financing standards, education assessment standards, process standards, and the standards of educators and education personnel are in the sufficient category. So, overall, the achievement of eight national education standards is still in the sufficient category.

Evaluating the input dimension, from the 11 parameters surveyed, the performance of non-formal education institutions was still in the low category. An evaluation of the process dimension found that of the five parameters surveyed, the performance of the non-formal education institution in Maluku was in the unfavorable category. Non-formal education management information system is not good yet; planning documents to evaluation and monitoring have not been applied consistently; implementation is incompatible with planning. Curriculum planning documents have not been designed in accordance with the essence of non-formal education. The curriculum is still formalistic-centralistic and does not involve students. Inconsistencies occurred between the learning planning document and the teacher's performance. Teacher accentuation tends to be in compliance and not in performance. An evaluation of the product dimension found that of the eight parameters surveyed, the performance of the non-formal education institution in Maluku was in the moderate category. Institutionally, the non-formal education institute has not generated any products of economic value because of the inability to analyze market needs; then unable to compete with similar products produced by local communities.

\section{REFERENCES}

[1] J. Simac, R. Marcus, and C. Harper, "Does non-formal education have lasting effects?" Compare, vol. 51, no. 5, pp. 706-724, 2019, doi: 10.1080/03057925.2019.1669011.

[2] J. Kalenda and I. Kočvarová, "Participation in non-formal education in risk society," Int. J. Lifelong Educ., pp. 1-14, 2020, doi: 10.1080/02601370.2020.1808102.

[3] E. Opdecam and P. Everaert, "Seven disagreements about cooperative learning," Account. Educ., vol. 27, no. 3, pp. 223-233, 2018, doi: 10.1080/09639284.2018.1477056.

[4] L. Norqvist and E. Leffler, "Learning in non-formal education: Is it 'youthful' for youth in action?" Int. Rev. Educ., vol. 63, no. 2, pp. 235-256, 2017, doi: 10.1007/s11159-017-9631-8.

[5] P. Serdyukov, "Innovation in education: what works, what doesn't, and what to do about it?" J. Res. Innov. Teach. Learn., vol. 10, no. 1, pp. 4-33, 2017, doi: 10.1108/jrit-10-2016-0007.

[6] R. Djalante, et al., "Review and analysis of current responses to COVID-19 in Indonesia: Period of January to March 2020," Prog. Disaster Sci., vol. 6, pp. 1-9, 2020, doi: 10.1016/j.pdisas.2020.100091.

[7] A. Fenanlampir, J. R. Batlolona, and I. Imelda, "The struggle of Indonesian students in the context of TIMSS and PISA has not ended," Int. J. Civ. Eng. Technol., vol. 10, no. 2, pp. 393-406, 2019.

[8] E. M. Meyers, I. Erickson, and R. V. Small, "Digital literacy and informal learning environments: An introduction," Learn. Media Technol., vol. 38, no. 4, pp. 355-367, 2013, doi: 10.1080/17439884.2013.783597.

[9] A. Martin and J. Grudziecki, "DigEuLit: Concepts and Tools for Digital Literacy Development," Innov. Teach. Learn. Inf. Comput. Sci., vol. 5, no. 4, pp. 249-267, 2006, doi: 10.11120/ital.2006.05040249.

[10] I. Sander, "What is critical big data literacy and how can it be implemented?" Internet Policy Rev., vol. 9, no. 2, pp. 1-22, 2020, doi: 10.14763/2020.2.1479.

[11] Z. Ezziane, "Information technology literacy: Implications on teaching and learning," Educ. Technol. Soc., vol. 10, no. 3, pp. 175-191, 2007.

[12] C. Chin and J. Osborne, "Students' questions: A potential resource for teaching and learning science," Stud. Sci. Educ., vol. 44, no. 1, pp. 1-39, 2008, doi: 10.1080/03057260701828101.

[13] L. E. Skibbe, A. H. Hindman, C. M. Connor, M. Housey, and F. J. Morrison, "Relative Contributions of Prekindergarten and Kindergarten to Children's Literacy and Mathematics Skills," Early Educ. Dev., vol. 24, no. 5, pp. 687-703, 2013, doi: 10.1080/10409289.2012.712888.

[14] S. A. Mirhosseini, M. Shirazizadeh, and H. Pakizehdel, "Bridging Language Education and "New Literacy Studies': Reinvigorating Courses of General English at an Iranian University,” J. Lang. Identity Educ., pp. 1-16, 2020, doi: 10.1080/15348458.2020.1791713. 
[15] R. Kurt, "Industry 4.0 in Terms of Industrial Relations and Its Impacts on Labour Life," Procedia Comput. Sci., vol. 158, pp. 590-601, 2019, doi: 10.1016/j.procs.2019.09.093.

[16] U. Sharma, C. Forlin, B. Sprunt, and L. Merumeru, "Identifying disability-inclusive indicators currently employed to monitor and evaluate education in the pacific island countries," Cogent Educ., vol. 3, no. 1, pp. 1-17, 2016, doi: 10.1080/2331186X.2016.1170754.

[17] A. E. J. Wals, Y. Mochizuki, and A. Leicht, "Critical case-studies of non-formal and community learning for sustainable development," Int. Rev. Educ., vol. 63, no. 6, pp. 783-792, 2017, doi: 10.1007/s11159-017-9691-9.

[18] Z. Notanubun, R. L. Ririhena, and J. R. Batlolona, "The effect of organization restructuring on organization performance viewed from employee performance and leadership effectiveness at Maluku provincial education office," J. Educ. Learn., vol. 13, no. 1, p. 118-124, 2019, doi: 10.11591/edulearn.v13i1.11222.

[19] T. Sharpe, "Ethical issues in domestic building performance evaluation studies," Build. Res. Inf., vol. 47, no. 3, pp. 318-329, 2019, doi: 10.1080/09613218.2018.1471868.

[20] F. Stevenson, "Embedding building performance evaluation in UK architectural practice and beyond," Build. Res. Inf., vol. 47, no. 3, pp. 305-317, 2019, doi: 10.1080/09613218.2018.1467542.

[21] N. Motefakker, "The Study of the Level of Satisfaction of the Students of the Faculty of Social Sciences with Welfare Services of Imam Khomeini International University of Qazvin,” Procedia Econ. Financ., vol. 36, no. 16, pp. 399-407, 2016, doi: 10.1016/s2212-5671(16)30052-1.

[22] R. Alonderiene and M. Majauskaite, "Leadership style and job satisfaction in higher education institutions," Int. J. Educ. Manag., vol. 30, no. 1, pp. 140-164, 2016, doi: 10.1108/IJEM-08-2014-0106.

[23] H. Eshach, "Bridging in-school and out-of-school learning: Formal, non-formal, and informal education," J. Sci. Educ. Technol., vol. 16, no. 2, pp. 171-190, 2007, doi: 10.1007/s10956-006-9027-1.

[24] M. T. B. Kalaw, "Tracer study of bachelor of science in mathematics," International Journal of Evaluation Research in Education (IJERE), vol. 8, no. 3, pp. 537-548, 2019, doi: 10.11591/ijere.v8i3.17343.

[25] A. M. A, "The Use of Technology in English Language Teaching," Front. Educ. Technol., vol. 2, no. 3, pp. 168-180, 2019, doi: 10.22158/fet.v2n3p168.

[26] J. Li, C. Snow, J. Jiang, and N. Edwards, "Technology use and self-perceptions of English language skills among urban adolescents," Comput. Assist. Lang. Learn., vol. 28, no. 5, pp. 450-478, 2015, doi: 10.1080/09588221.2014.881387.

[27] R. Ahmmed, B. S. Sinha, D. R. Khan, and D. M. Islam, "A needs analysis of maritime English language skills for Bangladeshi seafarers to work on-board ships," Mar. Policy, vol. 119, pp. 1-14, 2020, doi: 10.1016/j.marpol.2020.104041.

[28] Y. Y. Cloudia Ho, "Communicative language teaching and English as a foreign language undergraduates' communicative competence in Tourism English," J. Hosp. Leis. Sport Tour. Educ., vol. 27, no. 1, pp. 1-16, 2020, doi: 10.1016/j.jhlste.2020.100271.

[29] R. Bond, J. Curran, C. Kirkpatrick, N. Lee, and P. Francis, "Integrated impact assessment for sustainable development: A case study approach," World Dev., vol. 29, no. 6, pp. 1011-1024, 2001, doi: 10.1016/S0305750X(01)00023-7.

[30] S. Naudeau, W. Cunningham, M. K. A. Lundberg, and L. McGinnis, "Programs and policies that promote positive youth development and prevent risky behaviors: an international perspective," New Dir. Child Adolesc. Dev., vol. 2008, no. 122, pp. 75-87, 2008, doi: 10.1002/cd.230.

[31] M. Greaves, M. Nabhani, and R. Bahous, "Shelter in a storm: A case study exploring the use of psycho-social protection Strategies in non-formal refugee education in Lebanon," Int. J. Educ. Dev., vol. 66, pp. 70-77, 2019, doi: 10.1016/j.ijedudev.2019.02.005.

[32] J. Diaz, A. K. Chaudhary, K. S. U. Jayaratne, and E. Assan, "Expanding evaluator competency research: Exploring competencies for program evaluation using the context of non-formal education," Eval. Program Plann., vol. 79, pp. 1-10, 2020, doi: 10.1016/j.evalprogplan.2020.101790.

[33] K. A. Gee, "Achieving gender equality in learning outcomes: Evidence from a non-formal education program in Bangladesh," Int. J. Educ. Dev., vol. 40, pp. 207-216, 2015, doi: 10.1016/j.ijedudev.2014.09.001. 